\title{
TYPOLOGY OF THE DISTRICTS IN CZECHIA BASED ON LAND COVER STRUCTURE
}

\begin{abstract}
BALEJ, M., ANDĚL, J. (2011): Typology of the districts in Czechia based on land cover structure. Geografie, 116, No. 2, pp. 172-190. - The authors analyse land cover changes in Czechia after 1990 on a meso-scale, i.e., on the administrative unit/district scale. The CORINE land cover database makes it possible to compare land cover differences and similarities in 1990, 2000 and 2006. The objective of this report is to set out a district typology according to land cover structure, and this will be achieved through the use of statistical methodologies. An intermediate objective is to establish land cover change trends and tendencies, including the intensity and spatial differentiation of these changes. An additional objective is to designate the main driving forces behind these changes. The presumption that land cover in Czechia is tending to become a multi-functional landscape has not been confirmed at the district scale. In contrast, in some districts, monofunctionality is increasing regarding the frequency of land cover classes.
\end{abstract}

KEY WORDS: land cover changes - districts - driving forces - Czechia.

The research presented was supported by the Grant Agency of Academy of Sciences, project No. IAA311230901 "Czech Borderland after Schengen: a Distinct, Oscillating and/or Transit Area?".

\section{Introduction}

In general, land cover is defined as the observed (bio)-physical cover of the Earth's surface. It includes vegetation and man-made features, as well as bare rock, bare soil and inland water surfaces (Herold et al. 2006).

One of the most frequently cited definitions of the terms "land use" and "land cover" is "land use = land cover + land utilization" (Burley 1961). This definition suggests that the terms are not synonyms. Land cover is defined as that which one can observe on the surface of the Earth, whereas land use relates to the manner in which these biophysical assets are used by humans (Cihlar, Jansen 2001). Because use depends largely on land characteristics (i.e. cover, form, position, substratum), there is a close relationship between land cover and land use. However, the observation of land cover does not automatically result in a definition of land use because land cover and land use, although interrelated, are not identical (Jansen, Di Gregorio 2003; Lindgren 1985).

The development of land cover structures can be analysed on a broad range of spatial scales. Based on the precision of the database used, land cover structure can be monitored on micro-, meso- and macro-scales, all the way up to a global scale. Our objective in this study was to analyse and evaluate land cover changes on a meso-scale (in the terminology of the European NUTS4 
classification districts). The trends found on a meso-scale or districtal scale and their evaluation are different from (or complementary to) those found on a macro-regional scale (NUTS3). Districtal scales are more detailed and allow a deeper examination of land cover structure than at a macro-regional scale.

We posed the following questions: in what ways has land cover changed in Czechia since the fall of communism in 1989; what are the prevailing trends in the development of land cover on a meso-scale; how has land cover structure differentiated in the different districts of Czechia; can we detect similarities and cluster the individual districts into specific types; can we arrive at a typology of districts based on land cover changes; and in what ways have land cover changes impacted on other basic economic and social characteristics of the districts and Czechia and vice versa?

\section{Methods}

To monitor the internal heterogeneity of land cover in Czechia and its development on a meso-scale, we used the CORINE land cover (CLC) database. The CLC project is a major database tool for the comprehensive assessment of landscape development (e.g. Iovanna, Vance 2007; Kusimi 2008; Walsh, Evans, Turner II 2004; Porter-Bolland, Ellis, Gholz 2007). It is suitable for the purpose of performing spatial analyses at various scales (predominantly at regional and nationwide scales, that is, at a larger scale). This report concerns the territory of Czechia (approximately $79,000 \mathrm{~km}^{2}$ ).

The vector database CLC1990 was generated through the interpretation of satellite images from LANDSAT 5 TM taken between 1989 and 1992. Because of the need to update land cover data, in 1999 the European Environment Agency started to work with the European Commission's Joint Research Centre on the IMAGE2000 and CLC2000 projects (I\&CLC2000, e.g. Perdigao, Annoni 1997; Steenmans, Perdigao 2001; Nunes de Lima 2005; Feranec et al. 2007). The IMAGE2000 project led to the creation of a database of satellite images of Europe taken from the LANDSAT 7 ETM satellite senzor. CLC2006 is the direct continuation of earlier activities connected with CORINE Land Cover mapping.

With the aim of ensuring the comparability of the two databases, the primary methodological principles for processing the satellite images were retained. The minimum mapping unit was set at $25 \mathrm{ha}$, and the minimum width of mapped linear objects was $100 \mathrm{~m}$. The output was land cover maps at a scale of 1:100,000 with 44 land cover classes for European countries (Table 1).

To analyse the spatial differentiation of land cover classes in districts, we used the following statistical methods: a Euclidean metric similarity matrix, the cophenetic correlation coefficient, a cophenetic matrix, standard deviation and a dendrogram. We also used the Patch Analyst software application and calculated several landscape metrics (Patch Density and Shannon Diversity Index).

To calculate statistical data in individual time periods $(1990,2000,2006)$ we used the Statistica 9 software application. We performed our calculations based on relevant data for land cover classes to prevent distortion of the results due to the varying sizes of the districts. The objective was to determine 
1. Artificial surfaces

1.1. Urban fabric

1.1.1. Continuous urban fabric

1.1.2. Discontinuous urban fabric

1.2. Industrial, commercial and transport units

1.2.1. Industrial or commercial units

1.2.2. Road and rail networks and associated land

1.2.3. Port areas

1.2.4. Airports

1.3. Mine, dump and constructions sites

1.3.1. Mineral extraction sites

1.3.2. Dump sites

1.3.3. Construction sites

1.4. Artificial, non-agricultural vegetated areas

1.4.1. Green urban areas

1.4.2. Sport and leisure facilities

2. Agricultural areas

2.1. Arable land

2.1.1. Non-irrigated arable land

2.2. Permanent crops

2.2.1. Vineyards

2.2.2. Fruit trees and berry plantations

2.3. Pastures and meadows (grasslands)

2.3.1. Pastures and meadows (grassland)
2.4. Heterogeneous agricultural areas

2.4.2. Complex cultivation patterns

2.4.3. Land principally occupied by agriculture with significant areas of natural vegetation

3. Forest and semi-natural areas

3.1. Forests

3.1.1. Broad-leaved forests

3.1.2. Coniferous forests

3.1.3. Mixed forests

3.2. Scrub and/or herbaceous vegetation associations

3.2.1. Natural grasslands

3.2.2. Moors and heathland

3.2.4. Transitional woodland-scrub

3.3. Open spaces with little or no

vegetation

3.3.2. Bare rocks

3.3.4. Burnt areas

4. Wetlands

4.1. Inland wetlands

4.1.1. Inland marshes

4.1.2. Peat bogs

5. Water bodies

5.1. Inland waters

5.1.1. Water courses

5.1.2. Water bodies

the similarity in the frequency of land cover classes in individual years and find trends of change.

The Euclidean metric similarity matrix was calculated as an nth-order Minkowski metric, where $\mathrm{n}=16$. This $n$ is a generalised number of land cover classes existing in Czechia. Due to their insignificant rates, classes 322, 332, $334,411,412$ and 511 were omitted. In addition, the following similar and relatively small classes were merged into four classes: 111 and 112; 121, 122, 123, 124 and 133; 131 and 132; 141 and 142. The cophenetic correlation coefficient and cophenetic matrix express the degree of similarity between the districts and, through the dendrogram expressing the distance, indicate clusters of similar spatial units.

To compute the landscape metrics, Patch Analyst 3.12, which is a modified version of FRAGSTATS, was applied. FRAGSTATS is currently used by a number of landscape ecologists in their research (e.g. Abdullah, Nakagoshi 2006; Baskent, Kadiogullari 2007; Blaschke 2006; Botequilha Leitao, Ahern 2002; Corry 2004; Gergel, Turner 2003; Gustafson 1998; Krönert, Steinhardt, Volk 2001; Lausch, Herzog 2002; Li et al. 2001; Moser et al. 2002; Weaver, Perera 2004; Weng 2007). As an extension of ArcView, Patch Analyst is able to provide data on landscape patterns that are based on the composition and configuration of landscape elements (through polygonal shapes). The landscape metrics were computed for the landscape as a whole (landscape indices) and for polygons with selected identical attributes (particularly forest areas, 
pastures and meadows and arable land), that is, for patches of a particular type (class indices). We investigated the following parameters: Patch Density $(P D)$ and the Shannon's Diversity Index (SHDI; European Commission 2000; McGarigal, Marks 1994).

The total land cover change indices in the years between 1990, 2000 and 2006 were calculated according to the index:

$$
\text { Iclc }_{i}=1,000 \times \frac{\text { Area }_{i, t 2}-\text { Area }_{i, t 1}}{\text { Area } \times(t 2-t 1)_{1}}, \text { where }
$$

Area $_{i, t 2}$ is the area of the ith class in time $t 2 ;$ Area $_{i, t 1}$ is the area of the ith class in time $t 1$, i.e., at the start of the period; and Area is the total area of the district. The total district change index is the sum of the absolute values $I c l c_{i}$. The change index of individual classes was always calculated for $I=1$.

\section{Czechia after the fall of communism}

Post-communist developments in Czechia following the 1989 Velvet Revolution resulted in significant socio-economic changes and in changing the effects of human activity on the landscape. The political change that occurred it ha affected land cover in various parts of Czechia with differing intensities (Bičík, Jeleček 2005). In this study, we monitored these changes in three specific time periods: $1990,2000,2006$. These years also define different periods for Czechia's transforming economy.

The Velvet Revolution was preceded by a period of totalitarian communism (1948-1989), which can be understood as the final phase of an industrialised society (Hampl 1998). This period was marked by a departure from the natural trajectory of development in advanced western European countries, where the characteristics of a post-industrial society had begun to appear. At the beginning of the totalitarian period, citizens of German nationality (approximately three million residents of German nationality) were transfered from areas along the border of Bohemia, where the negative impact on the (cultural) landscape was the most intense. The structure of settlement in the region was disturbed. A number of smaller and larger buildings were destroyed, and entire settlements often ceased to exist. With the implementation of a centrally planned economy, which in agriculture, took the form of collectivisation and the nationalisation of private property (fields as well as private enterprises). As a result, the landscape structure and land use were unified. Numerous landmarks related to the region's history and art were deserted, and care for the landmarks was meagre. A landscape type designated as collective open fields was created (Meeus 1995).

The transformation period (1990-2000) represented the transformation from communism into a free society and a market economy and was connected to price liberalisation, extensive land and property privatisation and the formation of a new legislative and institutional framework. This period had strong ramifications on the social sphere, and this is also evidence for (the character and intensity of) agricultural activity and the landscape in general.

In the post-industrial period (after 2000), communications and information networks burgeoned in Czechia. The tertiary sector (services and tourism) ex- 
perienced dynamic development. The process of rurbanisation began, creating considerable pressure on the land in the hinterlands of major cities. Satellite towns, shopping and industrial zones emerged.

\section{Districts of Czechia (NUTS4)}

There is a long history of the districts within Czechia. These districts were formed as basic administrative units in 1850 based on an imperial decree, replacing the original manors. Thus, districts are mid-sized territorial units, into which the country's territory is divided (except Prague) in accordance with Act No. 36/1960 Coll. on the Territorial Division of the State, as amended in 1960. Since the district of Jeseník was created on 1 January, 1996, Czechia has had 76 districts (Fig. 1). The City of Prague is not in any district. As part of the second phase of reforming the regional administration, district government offices in Czechia stopped operating on 31 December, 2002. After 1 January, 2003, the districts retained their regional judicial circuits, public prosecutors, several organisational units of the Police of Czechia and other governmental institutions, and districts are operated as statistical units. The running of the district government offices was taken over in part by municipal authorities in municipalities with expanded government administration experience. As a rule, the administrative wards are somewhat smaller than the districts.

At the district level (NUTS4), the economic and social polarity is far more apparent than in the macro-regions (regions - NUTS3). In addition to Prague, the hinterlands of the country's capital, Pilsen and Brno, all have strong showings. Prague's impact on the hinterlands (especially on the districts of PragueWest and Prague-East) is evident in the low level of unemployment (under $2 \%$ ), dynamic population growth driven by immigration (ca $5 \%$ in 2008), and residential construction growth (over 2,000 residential units completed in 2008). Together with Mladá Boleslav, the positive effect is also felt in other nearby districts, including Mělník and Beroun. In other parts of Czechia, regional capitals and their nearby districts are prospering, with the exception of the peripheral Jihlava area and the disturbed Ostrava and Ústí nad Labem areas. Pilsen and its hinterlands (the Pilsen-South district) also have an excellent macro-location between Prague and Bavaria. The impact of this location is low unemployment, dynamic population growth and growing residential construction. The Karlovy Vary region, which exhibits skyrocketing economic potential, is also reaping the benefits of its favourable geographical location. The Liberec district also has similar potential.

In addition to Prague and Brno, the Pardubice district is becoming one of the most significant centres of economic development in Czechia, with a growing population, ongoing housing construction and very low unemployment (below 4\%). The Hradec Králové district has similar characteristics, but to a lesser degree. Morava is somewhat falling behind the dynamic growth being experienced by the Bohemian districts. In the Morava region the sole exception is Brno and the hinterlands, where the highest number of economic pursuits is registered, and housing construction is booming.

In economic and social terms, the worst situation is found in the Ostrava area. The Karviná district, for example, is experiencing a population decrease. 


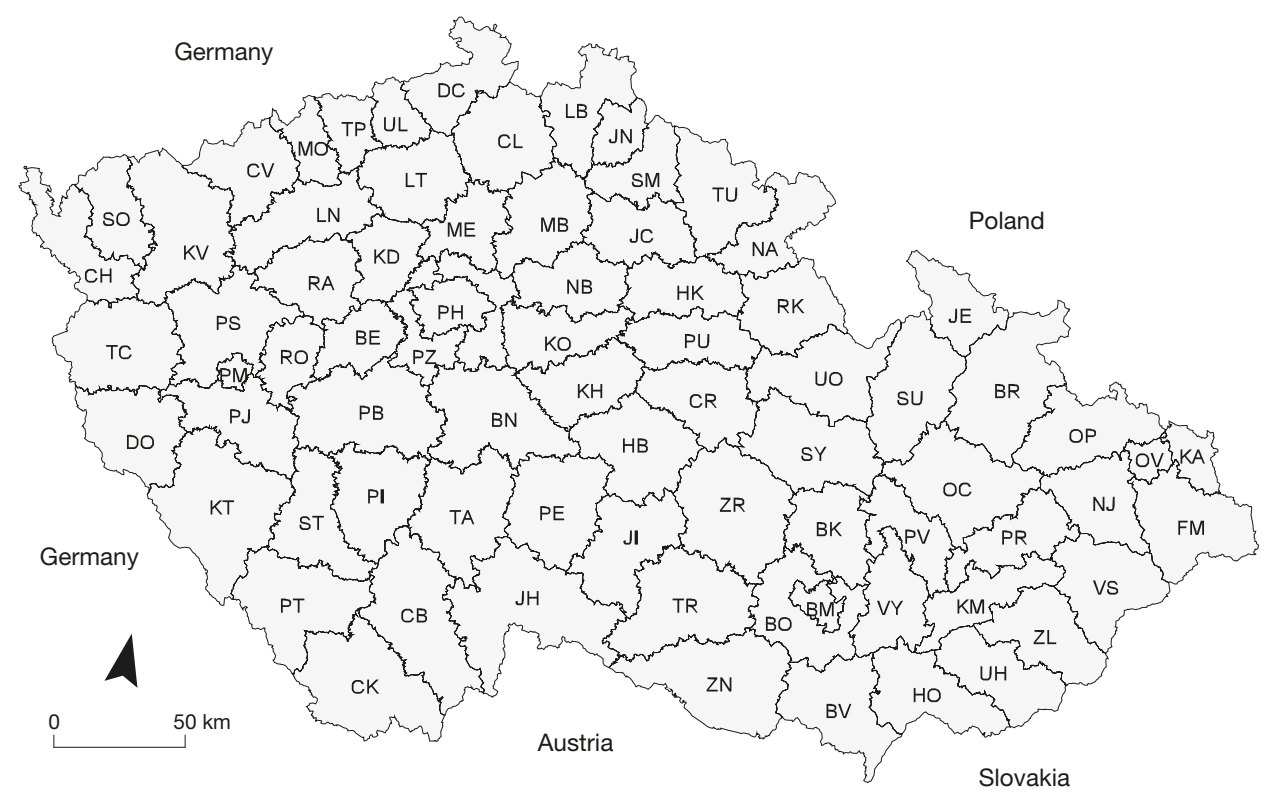

Fig. 1 - Districts of Czechia (NUTS4)

Unemployment is high, and the number of economic subjects is low. The situation is similar in the district of Bruntál. The situation is even worse in the district of Jeseník, where there is also minimal housing construction occurring. The situation in the districts (Chomutov, Most, Teplice, Ústí nad Labem) at the foot of the Ore Mountains (it belongs to Bohemia), where there is high unemployment, a low number of economic subjects and a low occurrence of housing construction, is similarly bleak.

It is generally the exposed areas in central Bohemia and the Pilsen and Brno areas that are economically and socially successful. As is prevalent in other parts of Europe, a socio-economic gradient is in effect here, which declines as it moves from west to east.

\section{Results}

In Czechia, the highest rate of arable land is found in the area along the Elbe River and the lower Ohře (Eger) River in central Bohemia and in southern Moravia, in the Moravian lowlands (Fig. 2). Arable land is rare at higher elevations, especially in the Czech border areas (with the exception of southern Moravia). The situation is completely reversed for forests.

The dominant change in land cover structure was observed in the decline of arable land in favour of other classes (predominantly pastures and meadows). In the first period, the decrease of arable land was greatest in the mountainous regions. The change index for this land cover category in the districts was as follows: Ústí nad Labem -18.3, Bruntál -16.1, Cheb -15.4 and Děčín -15.3 (see Fig. 2). In several districts in the most suitable areas for intensive 

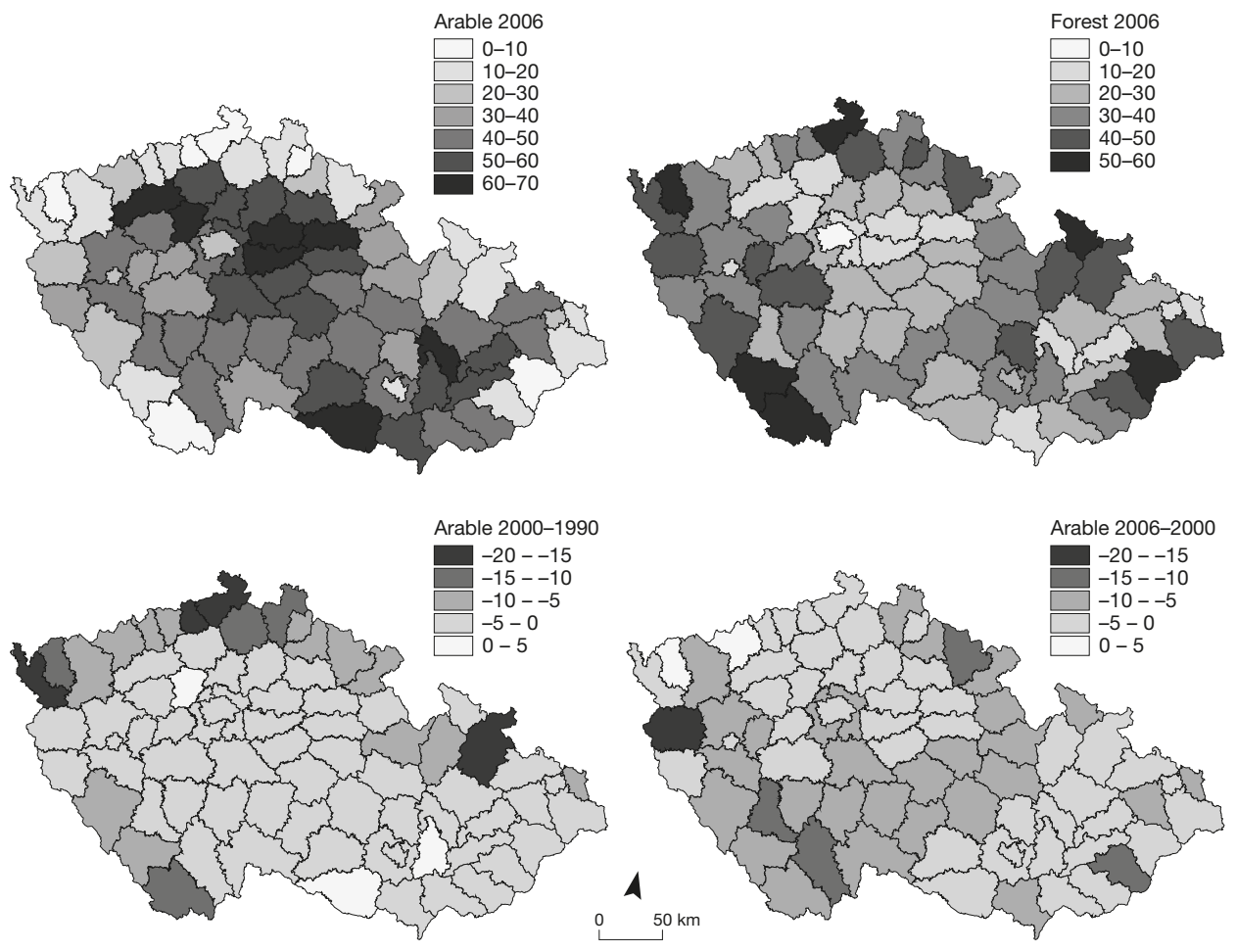

Fig. 2 - Ratio of arable land and forest in districts in 2006 and changes of arable land for 2006/2000 and 2000/1990 (in \%)

farming, the proportion of arable land grew just slightly (change index under 1 in Vyškov, Znojmo and Kladno).

In the second period, land also stopped being farmed at lower elevations and in hilly areas (Tachov 15.3, Trutnov 11.6, České Budějovice 10.7, Zlín 10.4, Strakonice 10.3). The decline in arable land was not as marked in this period. The most fertile districts in Czechia again experienced a small decline, or stagnation, in the amount of arable land. Growth of arable land in the districts of Sokolov and Chomutov was due to the very low rate of this category in the area and the gradual agricultural re-cultivation of former mines (mine reclamation).

An analysis of land cover structure and its development showed that in the transformation period, the greatest overall changes occurred in districts with a dissected, uneven terrain, particularly along the border with Saxony, in northern Moravia, and to some extent in the Sumava Mountains. In the posttransformation period, the greatest changes were again found in the mountainous districts, but new, significant changes were also observed in hilly and foothill regions (Fig. 3). The difference in the total index of changes for the two study periods in the Czech districts also shows a delay for internal peripheries, which are along the borders of the current regions. The development of the overall change index is predicated on the land cover category of arable land being changed, particularly into pastures and meadows. 

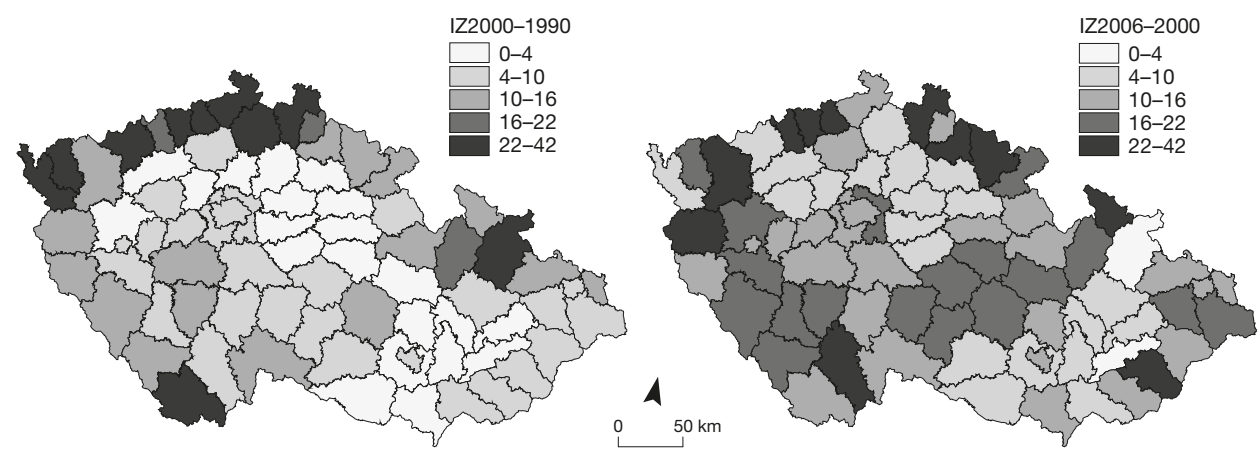

Fig. 3 - Development of the total index of land cover changes in the districts (changes 2000/ 1990 on the left and 2006/2000 on the right)

For the other land cover classes, there is a continuous increase in the share of urbanised spaces, industrial spaces and roads (111, 112, 122, 123, 124 and 133), where the 111 and 112 areas tripled in the second period, and 122, 123, 124 and 133 grew ten-fold. These classes are growing most in the hinterlands of the major agglomerations (Prague, Prague-East, Prague-West, Ostrava-City, Pilsen-City and Brno-City). Other districts also exhibited significant construction of industrial sites and shopping zones, including Mladá Boleslav, Semily, Ústí nad Labem, Liberec and Jablonec nad Nisou The increase in water surfaces in the Ústí nad Labem district is due to the filling of the Milada dam reservoir (formed from a brown coal mine reclamation project).

Pastures and meadows are growing in all of the districts, particularly in the border regions, with greater rates at higher elevations (in the post-transformation period: Tachov 13.5, Karlovy Vary 11.5, Trutnov 10.5; in the transformation period: Ústí nad Labem 17.2, Bruntál 15.9, Cheb 15.6, Děčín 15.1, Český Krumlov 13.2, Liberec 11.2 and Sokolov 10.2). The share of vineyards in the first period increased in all of the districts; in the second period, it fell in some districts (Uherské Hradiště - 0.3 , Litoměřice, Mělník and Louny -0.1) but rose in others (Břeclav 4.1, Znojmo 0.8, Hodonín 0.5, Brno - venkov 0.2).

In the first period, land principally occupied by agriculture with significant areas of natural vegetation changed only slightly; change was far more pronounced in the second period. This category was increased in the districts of Southern Bohemia, Southern Moravia and Vysočina.

Wooded vegetation expanded more intensively in the second period (in most cases, due to the impact of wooded re-vegetation of reclaimed brown coal surface mines): broad-leaved (deciduous) forest in Teplice 16, Most 10.7, Ústí nad Labem 9.6 and Sokolov 2.4. In other districts, this category increased by less than 1 (according to the change index for this category). Coniferous forests experienced the greatest change in the index in the post-transformation period in Jeseník (5.2), Frýdek-Místek (2.9) and Šumperk (2.8).

The CORINE database also makes it possible to calculate PD and SHDI. Figure 4 shows the results of these metrics and the standard deviation. When applying landscape metrics that were calculated for all classes altogether and for each category separately, it is necessary to consider the scale of the view of the landscape (the minimum mapped territorial unit in the CORINE da- 

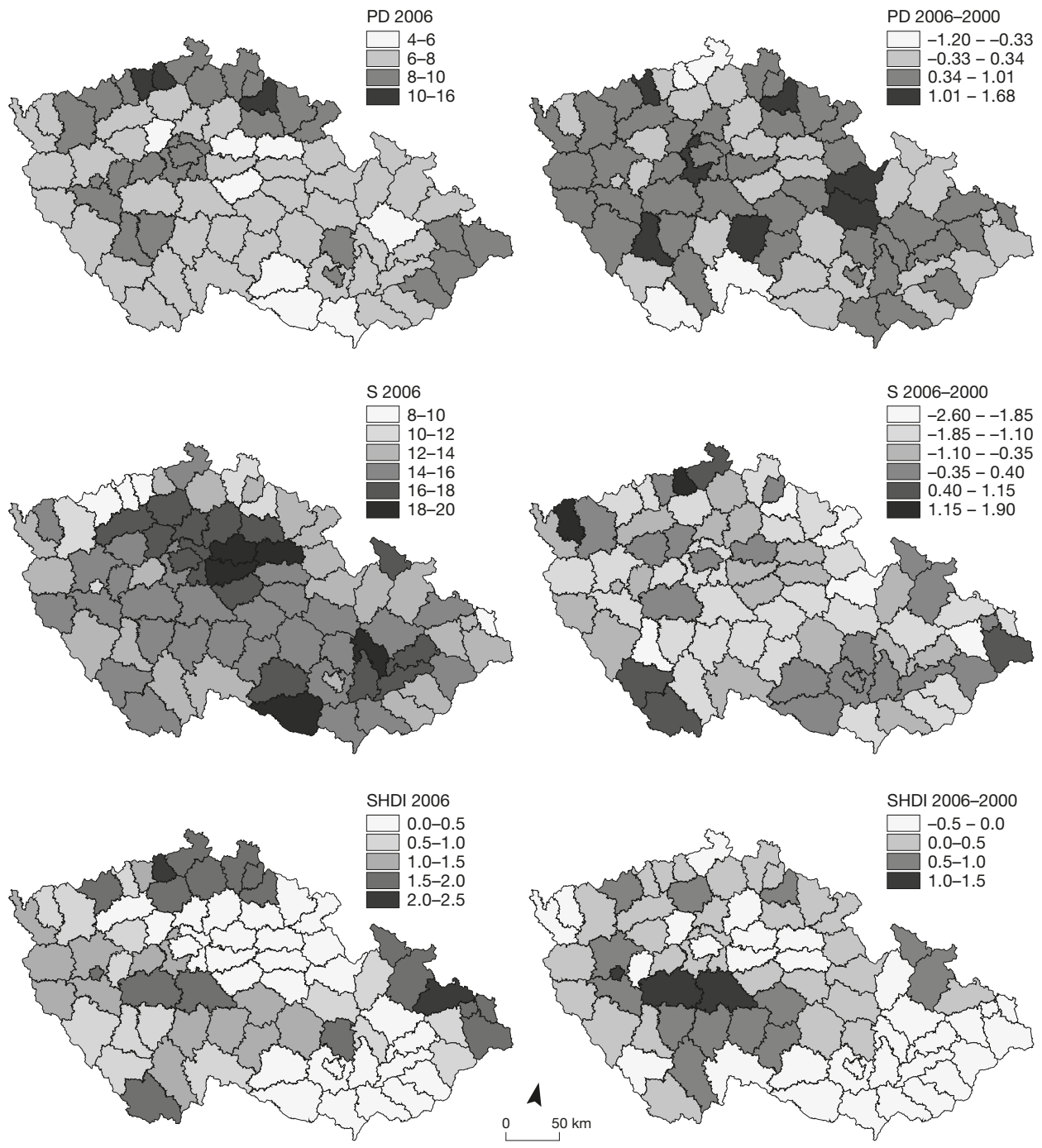

Fig. 4 - Patch density in 2006; changes of patch density 2006/1990; standard deviation in 2006 and changes of standard deviation 2006/1990; and Shannon diversity index in 2006 and changes 2006/1990 of the districts

tabase). This resolution is relatively coarse (25 ha). As a result, rather than individual land cover plots, the database captures areas where one category of land cover is predominant. Therefore, conclusions cannot be drawn about the microstructure of the landscape but rather about trends in the landscape's macrostructure.

Figure 4 confirms the hypothesis that wherever the standard deviation is high (i.e., a single category is significantly dominant) the Patch Density is low (e.g., the central territory of Bohemia and Southern Moravia with predominant arable land classes). More even rates of land cover classes imply that 
Table 2 - Examples of districts with the highest change of standard deviation $(S D)$ and with the lowest change of standard deviation of land cover classes

\begin{tabular}{|l|l|r|r|r|r|r|r|r|r|r|r|r|r|}
\hline Years & Districts & \multicolumn{9}{|c|}{ Land cover classes } & \multicolumn{1}{c|}{$S D$} \\
$2006 /$ \\
1990 \\
\cline { 2 - 15 } & & $1 \mathrm{xx}$ & 211 & 221 & 222 & 231 & 242 & 243 & $\begin{array}{l}311, \\
312, \\
313\end{array}$ & 321 & 324 & 512 & \\
\hline 2006 & $\begin{array}{l}\text { Ústí nad } \\
\text { Labem }\end{array}$ & 10.8 & 3.6 & 0.0 & 0.1 & 28.2 & 0.8 & 15.2 & 37.9 & 0.0 & 2.9 & 0.5 & 1.2 \\
\hline 1990 & $\begin{array}{l}\text { Ústí nad } \\
\text { Labem }\end{array}$ & 10.6 & 23.7 & 0.0 & 0.1 & 7.7 & 0.7 & 14.7 & 36.2 & 0.1 & 6.0 & 0.1 & \\
\hline 2006 & Náchod & 7.6 & 39.4 & 0.0 & 0.8 & 13.7 & 0.1 & 9.9 & 26.8 & 0.0 & 0.5 & 1.2 & -2.6 \\
\hline 1990 & Náchod & 7.2 & 50.3 & 0.0 & 0.5 & 4.0 & 0.1 & 9.5 & 26.4 & 0.0 & 0.8 & 1.2 & \\
\hline
\end{tabular}

Note: Land cover classes - see Table 1

there is a greater Patch Density. Some of the highest Patch Density values are also observed in the districts with a significant share of urbanised space (Karviná 15.3, Ostrava-City 12.8, Teplice 10.4, Ústí nad Labem 10.3, PilsenCity 10, Brno-City 9.9). Prague is not included in this list, as it is composed mainly of a single major category 111 space and only a small number of other categories, and it is approximately in the middle of the PD ranking. The lowest PD values are observed in districts with a high share of arable land (Znojmo 4.1, Nymburk 5.2, Kladno 5.2, Hradec Králové 5.4, Kutná Hora 5.7, Břeclav 5.8, Olomouc 5.8, Třebíč 5.9, Vyškov 6.0).

Regarding the standard deviation, the lower the value, the more balanced the share of individual land cover classes. Thus, the highest values are found in districts with a dominant share of arable land (Nymburk 19.7, Prostějov 19.2, Hradec Králové 19.0, Znojmo 19.0, Kolín 18.7). The high value in the Jeseník district (16.1) is due to its high percentage of forests (57\%). In contrast, the lowest standard deviations were found for the districts of Karviná 8.6, Chomutov 9.0, Most 9.1 and Teplice 10.0. A comparison of standard deviation in 1990 and 2006 shows that the values decreased in $80 \%$ of the districts, remained even in $10 \%$ and increased in $10 \%$. Examples of districts with the highest positive change and the greatest negative change are shown in Table 2. In the Ustí nad Labem district, not only did the dominant land cover category change, but the share of the dominant category also increased, and consequently, the standard deviation increased. The dominant category in the Náchod district did not change, but its proportion fell considerably in favour of other classes.

It is generally the case for SHDI that the greater the value, the more evenly each category is represented. At the same time, however, it is necessary to recognise that the SHDI also increases as the number of the category increases. The SHDI is, therefore, the inverse of the standard deviation but includes influence from the number of classes. Because of this, the results for the correlation between these variables for the individual districts in 2006, 2000 and 1990 were not surprising $(-0.5,-0.48,-0.47$, respectively). These rather weak correlations are predicated, based on the number of classes being changed. Some artificial surface classes did not exist in the seven districts in 2006 or in the nine districts in 1990; two classes, fruit trees and vineyards, were absent in 88 cases in 2006 and 86 cases in 1990; the natural grassland land cover category was absent in 33 districts in 2006 and 31 districts in 1990. 


\section{Discussion}

Political driving forces and the changes associated with them were the main reason behind land cover changes in Czechia after 1990 (according to McNeill et al., 1994). In general, political driving forces predicated the transformation of the centrally planned economy of Czechia into a market economy. Additional changes took place in the agricultural and industrial production sectors. These direct driving forces followed the political forces and resulted in a change in the composition of agricultural crops (grain crop area fell by $25 \%$, sugar beet crop area by 55\%), a reduction in livestock production (cattle stocks dropped by $45 \%$ ), a decline in the number of agriculture employees and other changes. The number of independent farmers increased (from 3,200 family farms in 1990 to 70,500 farms in 1999).

The sugar industry was also affected by Czechia's admission to to the European Union. Whereas sugar beets were grown on 120,000 hectares of land in 1990 , by 2008 , this had fallen to just 50,000 hectares. The low quota set for sugar production does not even cover Czech consumption. Although Czechia was traditionally a sugar exporter, it turned into an importer following the revolution. Whereas there were 52 sugar refineries in Czech lands in the 1980 s, currently there are only seven.

In contrast, rapeseed oil crop areas grew dynamically because of generous subsidies in concert with the promotion of alternative fuel production and the implementation of mandatory blends of these additives with petrol. As a result of the low quotas set by the EU, and cheap milk and dairy imports from Poland, dairy cattle stocks have also continued to decrease. A number of farmed spaces (pastures and meadows) have been deserted, and the natural process of succession has set in.

In addition to the reasons described above, natural determination has had an impact on the differentiation of land cover changes at the district scale in Czechia. After the market economy developed, production costs (including food) started to become more important, thus indirectly separating which areas in Czechia would be suitable for particular agricultural activities from areas that were less suitable. Because certain areas offer the lowest costs and highest returns, crop production is being concentrated into the most suitable areas of Czechia (with the most favourable climate, topographical and land conditions). The transformation into a market economy thus resulted in significant pressure related to adaptation to natural, as well as new economic (market) conditions (Rašín, Chromý 2010).

After land was returned to its original owners, the new owners often did not express interest in the personal land utilizing and let it lie fallow or rent to agricultural enterprises. In connection with the population's growing demands for quality housing and with the transformation into a post-modern society, satellite towns in the hinterlands of large agglomerations continue to be constructed (suburbanisation), and in some cases, the small-town way of life is becoming urbanised through the construction of houses and villas (re-urbanisation). The construction of new roads and investment incentives offered by Czechia have resulted growth of industrial space, construction sites and shopping zones.

Based on the structure and development of land cover, it is possible to construct a typology of the districts in which natural, economic, social and 


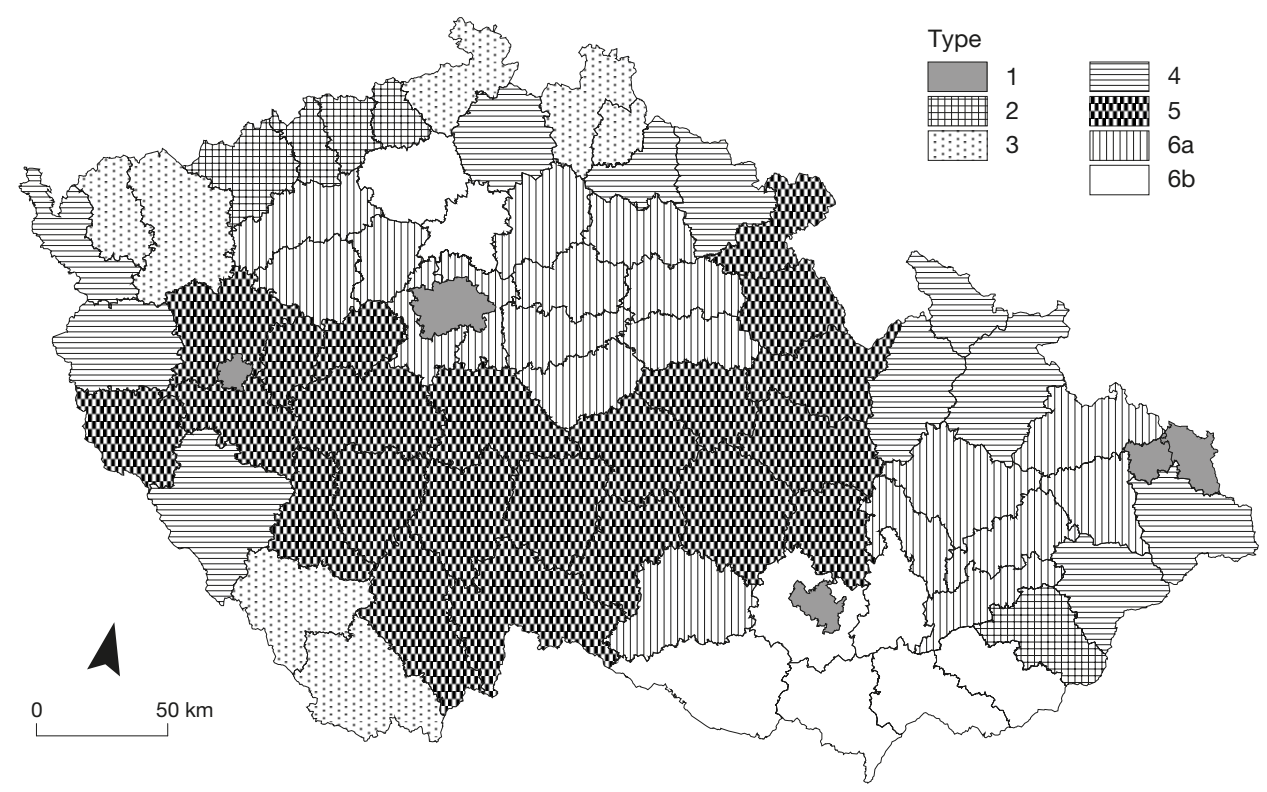

Fig. 5 - Typology of the districts based on land cover structure and changes

geographic location factors differ from one another, but are similar inside the type (Fig. 5). A dendrogram and cluster analysis (using Euclidean distance) were employed to compare the "distance" of land cover structures between all of the pairs of districts in 1990, 2000 and 2006, and as a result, we produced seven types of district structures.

The first two are the most stable and are relatively strictly defined types. 1. The metropolitan type represents the core regions (economic and transportation nodes) of Czechia: Prague, Pilsen, Ostrava (with Karviná) and Brno. These have a high rate of urbanised space (over 16\%) and industrial space (over 5\%) and a low rate of arable land (under 30\%) and forests. Development trends are tending to continue to strengthen their role as areas of concentration. In 1990-2000, this type was characterised by a marked increased in urbanised space, and in the period from 2000-2006, warehouse, industrial and road spaces increased. The 2nd type represents the structurally impaired area at the foothills of the Ore Mountains (Ústí nad Labem, Teplice, Most and Chomutov) and has similarly high rates of industrial and warehouse space (an average of $8 \%$ ) and a high rate of pastures and meadows (approximately 15\%), but a low share of arable land; the Ústí nad Labem district has the lowest rate in Bohemia (just 3.6\%). The greatest share of succession areas is observed in this region (the highest levels in Czechia are in Most with 20\% and Chomutov with $16.3 \%$ ), illustrating this landscape's past in the post-war period, when a significant part of the territory, particularly the area along the border with Saxony, stopped being used as agricultural land (Balej et al. 2008; Balej et al. 2010). Post-1990, there was a decrease in arable land, particularly in the first period. The growth in warehouse space (the district of Ústí nad Labem has the highest growth of this class in Czechia) illustrates the revival of economic 
activity in these depressed regions. The construction of the D8 motorway is also having an effect in these areas. The Zlín district, which exhibits similar characteristics, is approaching this type. This type also has high values for the overall change index, a high Patch Density and a low Standard Deviation.

The other types do not represent such sharply defined groups, and some districts are on the borderline between individual clusters. The 3rd and 4th types are composed of predominantly mountainous (border-area) districts. The 3rd type includes mostly industrial districts (a high share of the GDP is from industry). The Sokolov, Karlovy Vary, Děčín, Liberec and Jablonec nad Nisou districts are examples of this type. Most districts contain higher rates of urbanised and wooded space, whereas less of these districts is composed of arable land, for which the share dramatically decreased in the years from 1990-2000. In contrast, warehouse space increased in 2000-2006. The 4th type is distinct due to its peripheral location and extremely high forest cover (Vsetín and Jeseník have the highest in Czechia), and these areas have exhibited growth trends, especially in the 2nd period. The 5th highlands type is the most extensive in terms of area and includes the territories of the Central Bohemian Hills and Bohemian-Moravian Highlands. In its basic characteristics, the land cover in this type is near the Czech average. It is marked by its developmental stability, in addition to a slight increase in pastures and meadows, mostly during the 1 st period.

The 6th lowland and piedmontan type includes the Bohemian Plate, Prague Plateau, and the valleys and lowlands leading from Břeclav district to Ostrava in Moravia. It is marked by its high rate of both arable land and urbanised space and its relative developmental stability, though the relatively dynamic growth of pastures and meadows in Bohemian districts (Rakovník) during the first period, and in Moravian districts (Brno-venkov) during the second period, is an exception to this. A high level of developmental stability is also evident here, particularly in the period from 1990-2000. As part of the 6th type, we include the wine-growing type, designated as sub-type because of the rate of vineyards in these areas.

Overall, the assertion can be made that in accordance with general development trends (Musil, Müller 2008) and because of differentiation, the "distance" between the land cover structures of the districts increased in the years between 1990 and 2006 (Table 3). At the same time, in the large majority of districts, the rate of land cover classes has become more even. In the period from 1990-2006, the Average Euclidean Distance between Czech districts increased by $16.5 \%$. As expected, the most highly differentiated districts were the urbanised territories (Prague, Ostrava, Brno-City); in 1990, these regions also included Jablonec nad Nisou, and in 2006, they included Sokolov (especially influenced by a high rate of urbanised spaces and forests and a minimal share of arable land). In 2006, Ústí nad Labem had become the most highly specified district with the lowest share of arable land in Czechia and the highest share of pastures and meadows. In contrast, in 1990, the most typical districts (with the lowest average values of mutual "distances") could be found in eastern Bohemia (Ústí nad Orlicí, Ždár nad Sázavou and Náchod), in addition to Uherské Hradiště and Beroun. Písek a České Budějovice were added to these in 2000. The maximal levels of Average Euclidean Distance are increasing, but some minimum levels are falling. The minimum value 
Table 3 - Average Euclidean Distance (AED) of Czech districts, maximal and minimal AED based on the cophenetic matrix in 1990 and 2006

\begin{tabular}{|llll|}
\hline 1990 & AED & Districts \\
\cline { 2 - 4 } & Maximum value & 54.9 & $\begin{array}{l}\text { Praha, Ostrava-město, Vsetín, Brno-město, } \\
\text { Jablonec nad Nisou }\end{array}$ \\
\cline { 2 - 4 } & Minimum value & 19.4 & $\begin{array}{l}\text { Ústí nad Orlicí, Uherské Hradiště, Žd’ár nad } \\
\text { Sázavou, Beroun, Náchod }\end{array}$ \\
\cline { 2 - 4 } 2006 & Total & 26.7 & $\begin{array}{l}\text { Praha, Ostrava-město, Ústí nad Labem, } \\
\text { Brno-město, Sokolov }\end{array}$ \\
\cline { 2 - 4 } & Minimum value & 22.5 & $\begin{array}{l}\text { Uherské Hradiště, České Budějovice, Beroun, } \\
\text { Písek, Ždár nad Sázavou }\end{array}$ \\
\cline { 2 - 4 } & Total & 31.1 & \\
\hline
\end{tabular}

of 2.3 observed in 1990 for Chrudim-Jihlava had decreased to 1.5 by 2006 (Benešov-Havlíčkův Brod). Similarly, the maximum value observed rose from 70.2 (Prague-Vsetín) to 74.5.

Generally, the distances between the districts are increasing. For example, of the ten strongest connections in 1990,40\% increased (the distance between the pairs Pardubice - Opava and Kolín - Prague-East exhibited the greatest increases, by $84 \%$ and $70 \%$, respectively). This trend demonstrates the dynamics of change that have occurred in the metropolitan areas. Thirty per cent of the connections remained at the same levels (in 1990 and 2006), which were predominantly of the 6th type of district, which are marked by the greatest level of stability. The remaining $30 \%$ represent districts where the short distances were decreased even further. This decrease occurred in various types of districts, such as the 5th highland type, where the distance between the Benešov - Havlíčkův Brod pair was halved, and the 5th type (peripheral location with high forest cover - Česká Lípa vs. Šumperk). Additionally, in general, connections that were relatively direct in the first period (connections between pairs of districts) have become significantly more complicated, and various connected clusters are arising.

Together with other factors, political changes significantly affected the structure and development of land cover in Czech districts in the period from 1990 to 2006. In terms of the structure of land cover classes, it has been shown that there is growing heterogeneity in the Czech regions. At the beginning of the transformation period (before 1989), the uniformity imposed by central planning was highly evident. The role of natural conditions was relatively unimportant, and the structure of land cover classes was similar in the districts. Besides the central planning, the land cover structure was influenced by subsidies for farmers in less favoured areas and, on the other hand, by higher taxes for those farming in fertile agricultural areas. However, in the following years, the question of whether natural conditions were suitable for agricultural activities or not started to become crucial for developing human activity.

Individual types of districts have been growing more distant from one another, but at the same time, examples of district pairs in which land cover 
structures are becoming more similar to one another can also be found. The trend of one of the land cover classes becomes increasingly dominant can be seen in the country's remote districts with predominantly fewer suitable conditions for agricultural activity. The districts in the interior with suitable conditions for agricultural activity are, for the most part, stagnating or exhibiting only a very slight increase in the evenness of the rate of other classes. In the hilly regions, the evenness in the rate of land cover classes is significantly increasing.

On the districtal scale, as compared to the macro-scale (Czech regions), it can be expected that natural determinant factors (elevation, climate, land) should be more strongly reflected in the development of "land cover" classes, similar to economic, social and geographic location conditions. Very strong analogies with the typology of rural space in Czechia can be observed (Perlín, Kučerová, Kučera 2010). Examples of this are the 6th valley type, which nearly coincides with the "Developed Rural Area" type, and the 5th highland type, which is designated as "undifferentiated rural area" in rural typology, and type $6 \mathrm{~b}$ (vineyard) is similar to the "tourist Moravian rural area".

The determination for employing social capital is strong, particularly for the component referred to as "regional development" (Pileček, Jančák 2010), where metropolitan areas are assigned to one side and structurally impaired districts (the area at the foot of the Ore Mountains) to the other. Similar correlates can be found with region typologies in terms of the range of transportation options (Marada, Květoň 2010).

In defining individual types, it was confirmed that natural disposition and geographical location are of crucial importance for differentiating land cover structure and the development of this structure. To a certain extent, a dichotomy between the Bohemian and Moravian districts and between the border areas and the interior was observed (special development conditions after the transfer of the German population). Like the rural typology of Czechia (Perlín, Kučerová, Kučera 2010), the presented typology can serve as a basis for designing development studies, particularly of rural areas. Using this typology, support tools can be better formulated in relation to the specific aspects of individual parts of Czechia. Our results can provide the answer to the question of whether the development of the districts (NUTS4), thus far, has gone in the right direction, or whether the opposite is true. What impact and what effect do European grants have? This methodology can contribute to evaluating development trends in land cover category changes and, in comparison with current driving forces, indicate the next possible directions for further development.

It would be of great interest to analyse the Czech landscape using the same methodologies at the micro-scale (individual municipalities) in increasing detail, so that landscape elements that the CORINE database is incapable of capturing (game refuges, solitary trees, balks, avenues of trees, wildlife corridors, shoreline vegetation, small areas of water and many more elements) could be included in this research. Changes in the rate of these landscape elements in the landscape structure, their location, isolation and interconnection, shape characteristics and trends in development would provide additional complementary information about the Czech landscape. 


\section{References:}

ABDULLAH, S.A., NAKAGOSHI, N. (2006): Changes in landscape spatial pattern in the higly developing state of Selangor, peninsular Malaysia. Landscape Urban Plan, 77, No. 3, pp. 263-275.

BALEJ, M., ANDĚL, J., ORŠULÁK, T., RAŠKA, P. (2008): Development of environmental stress in Northwestern part of Czech Republic - new approaches and methods. Geografie, 113, No. 3, pp. 320-336.

BALEJ, M, RAŠKA, P., ANDĚL, J., CHVÁTALOVÁ, A. (2010): Memory of a Landscape a Constituent of Regional Identity and Planning? In: Anděl, J., Bičík, I., Dostál, P., Lipský, Z. (eds.): Landscape Modelling: Geographical Space, Transformation and Future Scenarios. Urban and Landscape Perspectives, Volume 8, Springer-Verlag, Berlin-Heidelberg, pp. 109-123.

BASKENT, E.Z., KADIOGULLARI, A.I. (2007): Spatial and temporal dynamics of land use pattern in Turkey: A case study in Inegöl. Landscape Urban Plan, 81, No. 4, pp. 316-327.

BIĆ́K, I., JELEČEK, L. (2005): Political events factoring into land-use changes in Czechia in the 20th century. In: Milanova, E., Himiyama, Y., Bičík, I. (eds.): Understanding landuse and land cover change in global and regional context. Enfield, USA and Plymouth, UK: Science Publishers, pp. 165-186.

BLASCHKE, T. (2006): The role of the spatial dimension within the framework of sustainable landscapes and natural capital. Landscape Urban Plan, 75, No. 3-4, pp. 198-226.

BOTEQUILHA LEITAO, A., AHERN, J. (2002): Applying landscape ecological concepts and metrics in sustainable landscape planning. Landscape Urban Plan, 59, No. 2, pp. 65-93.

BURLEY, T.M. (1961): Land use or land utilization? Professional Geographer, 13, pp. 18-20.

CIHLAR, J., JANSEN, L.J.M. (2001): From land cover to land-use: a methodology for efficient land-use mapping over large areas. The Professional Geographer, 53, No. 2, pp. 275-289.

CORRY, R.C. (2004): Characterizing fine-scale patterns of alternative agricultural landscapes with landscape pattern indices. Landscape Ecol, 20, No. 5, pp. 591-608.

European Union, 2000: From land cover to landscape diversity in the European Union. Retrieved October 16, 2005, http://ec.europa.eu/agriculture/publi/landscape/index.htm.

FERANEC, J., HAZEU, G., CHRISTENSEN, S., JAFFRAIN, G. (2007): Corine land cover change detection in Europe (case studies of the Netherlands and Slovakia). Land Use Policy, 24, No. 1, pp. 234-247.

GERGEL, S.E., TURNER, M.G. (2003): Learning landscape ecology. A practical guide to concepts and techniques. New York: Springer, $315 \mathrm{pp}$.

GUSTAFSON, E.J. (1998): Quantifying landscape spatial pattern: What is the state of the art? Ecosystems, 1, pp. 143-156.

HAMPL, M. (1998): Reality, community and geographical organisation. Finding an integral order (in Czech). Charles University, Prague, 110 pp.

HEROLD, M., LATHAM, J.S., Di GREGORIO, A., SCHMULLIUS, C.C. (2006): Evolving standards in land cover characterization. Journal of Land Use Science, 1, No. 2-4, pp. 157-168.

IOVANNA, R., VANCE, C. (2007): Modelling of continuous-time land cover change using setallite imagery: an application from North Carolina. Journal of Land Use Science, 2, No. 3, s. 147-166.

JANSEN, L.J.M., Di GREGORIO, A. (2003): Land-use data collection using the "land cover classification system": results from a case study in Kenya. Land Use Policy, 20, No. 2, pp. 131-148.

KRÖNERT, R., STEINHARDT, U., VOLK, M., eds. (2001): Landscape balance and landscape assessment. Springer, New York, $538 \mathrm{pp}$.

KUSIMI, J.M. (2008): Assessing land use and land cover change in the Wassa West District of Ghana using remote sensing. GeoJournal, 71, No. 4, pp. 249-259.

LAUSCH, A., HERZOG, F. (2002): Applicability of landscape metrics for the monitoring of landscape change: issues of scale, resolution and interpretability. Ecol Indic, 2, No. 1, pp. 3-15.

LI, X., LU, L., CHENG, G., XIAO, H. (2001): Quantifying landscape structure of the Heihe River Basin, noth-west China using FRAGSTATS. Journal of Arid Environments, 48, No. 4 , pp. 521-535. 
LINDGREN, D., ed. (1985): Land use planning and remote sensing. Kluwer, 176 pp.

MARADA, M., KVĚTOŇ, V. (2010): Diferenciace nabídky dopravních příležitostí v českých obcích a sociogeografikcých mikroregionech. Geografie, 115, No. 1, pp. 21-43.

McGARIGAL, K., MARKS, J.B. (1994): FRAGSTATS - spatial pattern analysis program for quantifying landscape structure. Forest Science Department, Oregon State University, Corvallis, $141 \mathrm{pp}$.

McNEILL, J., ALVES, D., ARIZPE, L., BYKOVA, O., GALVIN, K., KELMELIS, J., MIGOT-ADHOLLA, S., MORRISETTE, P., MOSS, R., RICHARDS, J., RIEBSAME, W., SADOWSKI, F., SANDERSON, S., SKOLE, D., TARR, J., WILLIAMS, M., YADAV, S., YOUNG, S. (1994): Toward a Typology and Regionalization of land Cover and land Use Change: Report of Working Group B. In: Meyer, W.B., Turner II, B.L. (eds.) Changes in Land Use and land Cover: A Global Perspective. Cambridge, UK, pp. 55-72.

MEEUS, J. (1995): Pan-European landscapes. Landscape Urban Plan, 31, No. 1-3, pp. 57-79.

MOSER, D., ZECHMEISTER H.G., PLUTZAR, CH., SAUBERER, N., WRBKA, T., GRABHERR, G. (2002): Landscape patch shape complexity as an effective measure for plant species richness in rural landscapes. Landscape Ecol, 17, pp. 657-669.

MUSIL, J., MÜLLER, J. (2008): Vnitřní periferie v České republice, sociální soudržnost a sociální vyloučení. CESES, FSV UK, Praha, 52 pp.

NUNES de LIMA, M.V. (2005): IMAGE2000 and CLC2000. Products and methods. European Environment Agency and Joint Research Centre, Ispra. 150 pp.

PERDIGAO, V., ANNONI, A. (1997): Technical and methodological guide for updating CORINE land cover data base. JRC, EEA, Luxembourg, 124 pp.

PERLÍN, R., KUČEROVÁ, S., KUČERA, Z. (2010): Typologie venkovského prostoru Česka. Geografie, 115, No. 2, pp. 161-178.

PILEČEK, J., JANČÁK, V. (2010): Je možné měřit sociální kapitál? Analýza územní diferenciace okresů Česka. Geografie, 115, No. 1, pp. 78-95.

PORTER-BOLLAND, L., ELLIS, E.A., GHOLZ, H. (2007): Land use dynamics and landscape history in La Montana, Campeche, Mexico. Landscape and Urban Planning, 82, No. 4, pp. 198-207.

RAŠÍN, R., CHROMÝ, P. (2010): Land use and land cover development along the Czech-Austrian Boundary. In: Bičík, I., Himiyama, Y., Feranec, J. (eds.) Land Use/Cover Changes in Selected Regions in the World. Vol. 5, IGU-LUCC, pp. 57-65.

STEENMANS, CH., PERDIGAO, V. (2001): Update of the CORINE land cover database. In: Groom, G. (ed.): Reedlandscape monitoring for the Nordic countries. Nordic Council of Ministers, Copenhagen, pp. 101-107.

WALSH, S.J., EVANS, T.P., TURNER II, B.L. (2004): Population-environment interactions with an emphasis on land-use/land-cover dynamics and the role of technology. In: Brunn, S. D., Cutter, S. L., Harrington, J. W. (eds.): Geography and technology. Kluwer, pp. 491-519.

WEAVER, K., PERERA, A.H. (2004): Modelling land cover transitions: A solution to the problem of spatial dependence in data. Landscape Ecol, 19, No. 3, pp. 273-289.

WENG, Y. (2007): Spatiotemporal changes of landscape pattern in response to urbanisation. Landscape Urban Plan, 81, No. 4, pp. 341-353.

\section{Shrnutí}

\section{TYPOLOGIE OKRESŮ ČESKA NA ZÁKLADĚ STRUKTURY KRAJINNÉHO POKRYVU}

Vývoj struktury krajinného pokryvu v Česku po roce 1990 je výrazně prostorově diferencován a probíhá $\mathrm{v}$ různých oblastech rozdílně a s rozdílnou intenzitou. Vývojové trendy změn krajinného pokryvu lze sledovat prostrednictvím evropské databáze CORINE, která umožňuje porovnávat krajinný pokryv v letech 1990, 2000 a 2006. Monitorovanými územními jednotkami byly okresy.

K analýze tendencí krajinného pokryvu a prostorové diferenciace byly použity statistické metody (Euclidean metric similarity matrix, cophenetic correlation coefficient, cophenetic matrix, standard deviation a shluková analýza). Aplikován byl i software Patch Analyst pro 
zjištění některých krajinných metrik (hustota plošek a Shannon Diversity Index). K výpočtu statistických dat v jednotlivých časových horizontech $(1990,2000,2006)$ byl využit software Statistica 9. Euclidean metric similarity matrix byla počítána jako Minkowského metrika $n$-tého řádu, kde $n=16$. Cophenetic correlation coefficient a cophenetic matrix vyjadřují míru podobnosti struktury krajinného pokryvu okresů mezi sebou. Prostřednictvím shlukové analýzy bylo možné formulovat shluky podobných regionů.

Výsledky potvrzují hypotézu, že tam, kde je standardní odchylka vysoká, tedy zastoupení jedné třídy výrazně dominuje, tam je hustota plošek nízká (převážně se jedná o centrální území Česka a jižní Moravu s převahou orné půdy). Rovnoměrnější zastoupení tříd krajinného pokryvu implikuje vyšší hustotu plošek. Podle struktury a vývoje krajinného pokryvu je možné sestavit typologii okresů, jejichž struktura krajinného pokryvu je uvnitř typu obdobná a mezi typy odlišná.

V rámci Česka bylo vymezeno 7 typů (resp. 6 typů a 1 podtyp), kde byly následně interpretovány ekonomické, sociální a geopolohové faktory. Nejstabilnější a poměrně ostře vymezené jsou první dva typy. 1. typ (metropolitní) zahrnuje jádrové regiony Ćeska (Praha, Plzeň, Ostrava a Brno) s vysokým zastoupením urbanizovaných a průmyslových ploch, s nízkým podílem orné půdy a lesů. 2 . typ reprezentuje strukturálně postiženou oblast Podkrušnohoří s obdobně vysokým zastoupením průmyslových a skladovacích (logistických) ploch, s vysokým zastoupením luk a naopak s velmi nízkým podílem orné půdy. 3 . a 4. typ tvoří zejména horské, pohraniční okresy. 3. typ zahrnuje převážně průmyslové regiony s vyšším zastoupením urbanizovaných a lesních ploch, naopak menší podíl je orné půdy, který navíc mezi roky 1990-2000 poměrně dynamicky klesá. 4. typ se vyznačuje periferní polohou s velmi vysokou lesnatostí a s tendencemi růstu těchto ploch zejména ve 2. období (2000-2006). 5. typ (vrchovinný) je plošně nejrozsáhlejší a zahrnuje centrální území pahorkatin a vrchovin. 6. typ (nížinný) reprezentuje intenzivně zemědělsky využívané území s vysoce bonitovanými půdami. Vyznačuje se významným podílem jak orné půdy, tak urbanizovaných ploch a také relativní vývojovou stabilitou. V rámci 6 . typu můžeme navíc vyčlenit podtyp $\mathrm{s}$ vyšším zastoupením vinic.

Z hlediska struktury kategorií krajinného pokryvu byla prokázána rostoucí heterogenita okresů Česka. Před rokem 1989 se silně projevovala uniformita centrálního plánování, vyznačující se finančními dotacemi do méně př́hodných oblastí pro zemědělskou činnost (tzn. umělé dofinancování). Role prrírodních předpokladů nebyla vnímána jako podstatná, a struktura kategorií krajinného pokryvu tak byla více homogenní. V dalších letech vhodnost či nevhodnost (determinující charakter) přírodních podmínek začíná být daleko více podstatná. Na jedné straně se jednotlivé typy regionů ve struktuře krajinného pokryvu od sebe vzdalují a na straně druhé lze nalézt příklady dvojic, jejichž struktura krajinného pokryvu se stává navzájem podobnější. Tendence, kdy jedna ze tříd krajinného pokryvu nabývá na ještě větší dominanci, mají odlehlé (periferní) regiony s převážně méně vhodnými podmínkami pro zemědělské aktivity. Obecně lze vysledovat, že variabilita krajinného pokryvu mezi okresy roste, a to jak v průměru, tak v hodnotách maxima a minima.

Zajímavé by bylo stejnými metodami analyzovat krajinu Česka na mikroúrovni (obcí) tak, aby mohly být do výzkumu zahrnuty i krajinné prvky, které databáze CORINE není schopna zachytit (např. remízy, solitéry, meze, aleje, biokoridory, břežní vegetaci, drobné vodní plochy a mnohé další). Změny v zastoupení těchto prvků v mikrostruktuře krajiny, jejich rozmístění, izolovanost a propojenost, tvarové charakteristiky a tendence ve vývoji by přinesly další komplementární informaci o krajině Česka.

Obr. 1 - Okresy Česka (NUTS 4)

Obr. 2 - Podíl orné půdy a lesů v okresech (2006), index změny orné půdy v období 2006/2000 a $2000 / 1990(\mathrm{v} \%)$

Obr. 3 -Vývoj celkového indexu změny v okresech (vlevo změny 2000/1990, vpravo změny 2006/2000)

Obr. 4 - Hustota ploch (PD) v roce 2006, změny hustoty ploch 2006/1990, standardní odchylka (S) v roce 2006, změny standardní odchylky 2006/1990, Shanon Diversity Index $(S H D I)$ v roce 2006 a jeho změny $2006 / 1990$

Obr. 5 - Typologie okresů na základě struktury krajinného krytu a jeho změn. 
Authors' affiliations: J. E. Purkinje University, Faculty of Science, Department of Geography, České mládeže 8, Ústí nad Labem, 400 96, Czechia; e-mail: balej@sci.ujep.cz.

Initial submission, 6 December 2010; final acceptance, 11 March 2011.

Please cite this article as:

BALEJ, M., ANDĚL, J. (2011): Typology of the districts in Czechia based on land cover structure. Geografie, 116, No. 2, pp. 172-190. 